\title{
Evaluation of waters environment hazard by pulp-mill liquors
}

\author{
${ }^{1}$ Aleksandra Lewkiewicz-Małysa, ${ }^{2}$ Elżbieta Konopka \\ AGH-University of Science and Technology, Kraków, Poland \\ ${ }^{1}$ Faculty of Drilling, Oil and Gas \\ ${ }^{2}$ Faculty of Mining and Geoengineering, e-mail: ekonopka@agh.edu.pl
}

\begin{abstract}
Pulp-mill waste is very noxious for the primary wood production. The problems of its manageability are correlated with its volume and a considerable degree of pollutions, mainly the organic ones, coming from wood processing. The other main components of waste material are aggressive reagents liberating the cellulose fibers, during washing, classification and the benediction processes. The results of environmental studies covering the superficial water of the pulp-mill impact were presented. The production process factors were assessed owing to the waste concentration and distribution in the water race.
\end{abstract}

Keywords: chemical paper-pulp, pulp-mill waste, BAT, self-cleaning of waters.

\section{INTRODUCTION}

The cellulose-pulp of various origins, mainly obtained from natural materials of plants or of recycling origin, are the basic paper industry substrates. In the nonintegrated systems pulp mills produce a specific type of pulp, which being a free market product, is purchased by paper and cardboard plants. In the integrated system, a full processingand-production cycle is realized.

In the UE countries the Council Directive of 24 September 1996 on Integrated Pollution Prevention and Control (IPPC) is valid. Within the executive operations, accounting for the specific character of cellulose and paper sector, in December 2001 the European Commission worked out and then approved of the Reference Document on Best Available Techniques (BAT) in the Pulp and Paper Industry. This document is focused on the chemical paper-pulp and paper production methods used in the World ${ }^{1}$ :

- the process of cellulose materials sulfate pulping (kraft)

- the process of cellulose materials sulfite pulping

- the production of the mechanical and chemo-mechanical pulp

- the secondary materials processing

- paper and cardboard production and the accompanying processes.

The most frequently applied chemical method of paperpulp production is the kraft process $(80 \%$ of World's production), and only $10 \%$ of paper-pulp is obtained with the sulfite method. Higher applicability of the sulfate pulping method results from the fact that all kinds of wood can be used, the mass has better parameters and more effective systems of chemicals regeneration methods exist.

The cellulose-pulp and paper production in Poland has been analyzed in great detail on the basis of the source document. Special emphasis was put on the environmental impact of the production systems, including contaminations emission to waste watercourses (Ministry of Environment, Warsaw, 2005). A total of 39 paper producers generate about $2800 \mathrm{Mt}$ of various paper products every year. Annually paper industry uses on the whole about $1060 \mathrm{Mt}$ primary cellulose-pulp, which in $80 \%$ are obtained through the sulfate pulping method. Presently, 6 nonintegrated paper plants and 15 integrated plants realize the IPPC Directive: 3 of these plants use the sulfate method, one the semi-chemical (neutral sulfite) method and another 2 produce mechanical pulp. The remaining plants produce scrap paper-pulp ${ }^{2}$.

\section{METHODOLOGICAL BASES}

The basic products for the production of primary cellulose-pulp are mainly various kinds of wood, where cellulose dominates ( $45 \%$ calculated for dry mass). The remaining components are: lignin 25\%, hemicelluloses $25 \%$ and other organic and inorganic substances ca. 5\%. Cellulose fibres can be produced when wood is processed chemically, mechanically and chemo-mechanically. In sulfate and sulfite chemical pulping specific reagents dissolving lignin and part of hemicellulose are used. The conditions and advancement of cellulose fibres liberation determine the kappa number, which defines the admissible rest content of lignin in a specific type of cellulose-pulp, maintaining the required chemical wood paper-pulp properties ${ }^{\mathbf{1}}$.

In the sulfate method the so-called white liquor is applied with the chemically active $\mathrm{NaOH}$ and $\mathrm{Na}_{2} \mathrm{~S}$. The wood kiering process takes place at the increased temperature (150 to $180^{\circ} \mathrm{C}$ ) and pressure for many hours. The initial high $\mathrm{pH}$ value of 13 to 14 is gradually decreasing owing to the formation of organic acids as a product of a reaction with lignin. Delignification of, e.g. coniferous wood may be carried out to kappa value of 30 to 35 , in the case of deciduous wood the value is lower, i.e. 14 to 22 . About $50 \%$ of input wood mass undergoes pulping and the dissolved organic components make up the black liquor. Cellulose fibres may be separated with the use of washing and filtering apparatuses, and the effectiveness of the process depends on, among others, the quantity of applied water. The lignin left over in the cellulose mass may be removed in the oxygen delignification process. Depending on the kind of wood, unbleached cellulose mass is obtained (kappa equals to about 8 to 12). Lignin residues make cellulose-pulp rather dark ca. $30 \%$ ISO; the whiteness may be increased by about $90 \%$ if the lignin residues are removed. Bleaching in the sulfate chemical pulping process is performed with the use of, e.g. chloride dioxide in the presence of alkalies as lignin extractants. Lignin content in the bleached chemical mass drops to kappa $<1$. The classic and deepened delignification processes may take place in a closed system as the post-processing liquor undergoes thermal regeneration. In the bleaching process, slurry is produced and organic matter should be removed from it.

Unlike sulfate method, the sulfite pulping method can be realized in many variants, in the entire range of $\mathrm{pH}$ values. Moreover, it is determined by the chemical composition (active substance) of the liquor. Therefore, various types of 
Table 1. Characteristics of the sulfite pulping process

\begin{tabular}{|c|c|c|c|c|c|c|}
\hline No. & Method & $\mathrm{pH}$ & Alkalies & $\begin{array}{c}\text { Active } \\
\text { component }\end{array}$ & $\begin{array}{c}\text { Temp. } \\
{\left[{ }^{0} \mathrm{C}\right]}\end{array}$ & $\begin{array}{c}\text { Yield } \\
{[\%]}\end{array}$ \\
\hline 1 & Acid sulfite & $1-2$ & $\begin{array}{c}\mathrm{Ca}^{2+} \\
\mathrm{Mg}^{2+}, \mathrm{Na}^{+}\end{array}$ & $\begin{array}{c}\mathrm{SO}_{2}\left(\mathrm{H}_{2} \mathrm{O}\right) \\
\mathrm{H}^{+}, \mathrm{HSO}_{3}{ }^{-}\end{array}$ & $\begin{array}{c}125-143 \\
40-50\end{array}$ \\
\hline 2 & Acid sulfite & $3-5$ & $\mathrm{Mg}^{2+}, \mathrm{Na}^{+}$ & $\mathrm{HSO}_{3}{ }^{-}, \mathrm{H}^{+}$ & $150-170$ & $50-65$ \\
\hline 3 & $\begin{array}{c}\text { Neutral sulfite } \\
\text { (NSSC) }\end{array}$ & $5-7$ & $\mathrm{Na}^{+}, \mathrm{NH}_{4}{ }^{+}$ & $\mathrm{HSO}_{3}{ }^{-}, \mathrm{SO}_{3}{ }^{2-}$ & $160-180$ & $75-90$ \\
\hline 4 & Alkaline sulfite & $9-13.5$ & $\mathrm{Na}^{+}$ & $\mathrm{SO}_{3}{ }^{2-}, \mathrm{OH}^{-}$ & $160-180$ & $45-60$ \\
\hline
\end{tabular}

wood pulping can be employed, and consequently, various qualities and various applicability ranges of cellulose-pulps can be obtained. The following sulfite pulping methods are used in Europe (Table 1).

The cellulose plants in Europe employ the sulfite pulping procedure mainly with the use of magnesium base, thanks to which the post-production liquor can be utilized to a considerable extent. Active components of the pulping process are $\mathrm{MgSO}_{3}$ and $\mathrm{Mg}\left(\mathrm{HSO}_{3}\right)_{2}$ and they are responsible for the delignification of coniferous and deciduous wood to kappa equal to $14-22$ and $10-20$, respectively (maintaining the required chemical paper-pulp properties). The remaining lignins can be further removed in the process of sulfite oxygen delignification process to kappa $<10$. The unbleached cellulose mass is treated, and the remaining lignin is oxidized with the use of oxygen or hydrogen peroxide in the presence of sodium base as an organic matter extractant, till the moment the chemical paper-pulp reaches full whiteness. A by-product slurry is produced in the cellulose bleaching process. It contains a high organic matter content $\mathrm{COD}=35-120 \mathrm{kgO}_{2} / \mathrm{t}$ of the produced mass.

A specific kind of chemical paper-pulp is the semi-chemical pulp obtained with the neutral sulfite pulping method (NSSC - item 3 in Table 1). The comminuted material, i.e. deciduous wood (mainly birch wood) undergoes light chemical treatment with $\mathrm{Na}_{2} \mathrm{SO}_{3}$ in the presence of $\mathrm{Na}_{2} \mathrm{CO}_{3}$ as the $\mathrm{pH}$ stabilizer. The reagent causes softening and partial dissolving of lignin, and the obtained fibres are mechanically separated in a refiner. Owing to the rather low delignification level of cellulose-pulp used for cardboard production, this method has high ( $80 \%$ ) effectiveness. The main contamination load can be found in the post-production red liquor left over after the solid phase filtering. The fibre-pulp undergoes multistage washing with the use of filtering and dehydrating systems. In the case of the unintegrated system of reagents regeneration the slurry would contain a considerable charge of organic and mineral substances.

According to the assessed data ${ }^{1}$ the cellulose plants in Europe produce a considerable amount of organic substances annually: COD $=80-200 \mathrm{~kg} / \mathrm{t}$ of sulfite paper-pulp, and globally the amount of slurry (even in modernized plants) are twice as big as in the sulfate-based plants. The degree of slurry cleaning varies, which was indicated on the example of the selected indices for magnesium-sulfite cellulose plants (bleached mass production). For comparison's sake, analogous data were presented with the use of optimum BAT combinations in the cellulose sector. The data calculated per ton of air-dry cellulose-pulp (ADt) are presented in Table 2.
Both sulfate and sulfite chemical pulping methods reveal numerous similarities: comparable unit processes generate similar physicochemical consequences despite the application of various reagents. For this reason the range of monitoring and prevention of contaminants emission to water environment is similar. Post-production slurry contains a considerable amount of organic matter accompanying cellulose fibres, and which are removed during wood kiering, deep delignification and bleaching of the fibre-pulp, followed by washing and dehydration ${ }^{3}$. During the mixing (dissolving) of various technological waters in a plant, high $\mathrm{COD}=0.5-1.0$ $\mathrm{gO}_{2} / \mathrm{dm}^{3}$ of slurry was observed. The main organic contaminations present in the slurry are lignin, resin acids, lignin sulfonate acids, chlorination products: chlorolignins, chlorinated fatty acids. The problem of removing lignin compounds and resin acids by their oxidization in ozone-treatment processes is investigated. About $60 \%$ of lignin was degraded, and the products turned out to be more degradable. Resin acids may be nearly completely degraded when ozone treatment is employed $\mathrm{UV}+\mathrm{H}_{2} \mathrm{O}_{2}$, $, 5,6$.

Urged to follow the IPPC Directive, the cellulose-paper plant planners should account for economic results and also the System of Environmental Management (ISO 14001). For instance, a Polish integrated plant Mondi Packaging Paper Świecie S.A. has an automated monitoring and early warning system. Part of the measurements is made online in the course of sampling, when the COD, BOD, suspension and sulfate values are given on a regular basis. In this way the biologic slurry treatment plant is protected against an uncontrolled discharge of aggressive slurries. Contamination limits have been established and every single violation is analyzed in detail in view of the process stabilization ${ }^{7}$.

Mechanical pulp is also used for paper production. It is composed of very little processed cellulose fibres. Shear and friction forces are used for extracting cellulose fibres from wood material and most of lignin is retained in the pulp. Scrap paper is a secondary source of cellulose fibres.

\section{TECHNICAL AND ENVIRONMENTAL CONDITIONINGS}

The analysis and assessment of environmental influence of cellulose industry on water conditions was based on an exemplary plant in the north-eastern part of the Małopolska Province. The plant's area was located at a basin of two rivers feeding the Vistula river in its upper course. Both watercourses were differently used in the cellulose technological processing. The post-production water was collected from

Table 2. Residual impurities after sulfite pulp-mill liquors purification - average values per year

\begin{tabular}{|l|c|c|c|c|}
\hline \multirow{2}{*}{ Version: } & Flow & COD & \multicolumn{2}{c|}{ BOD } \\
\cline { 2 - 5 } & $\mathrm{m}^{3} / \mathrm{ADt}$ & \multicolumn{3}{|c|}{$\mathrm{kg} / \mathrm{ADt}$} \\
\hline by reports & $40-100$ & $10-190$ & $0.5-75.0$ & $1.7-10.0$ \\
\hline by BAT & $40-55$ & $20-30$ & $1.0-2.0$ & $1.0-2.0$ \\
\hline
\end{tabular}


the Dunajec river (1 km off the site), whereas the postproduction slurry was discharged through a canal to the Żabnica river (1.5 to $2.0 \mathrm{~km}$ off the site). The total length of the cellulose waste collector was about 65 to $70 \mathrm{~km}$, and the waste was discharged at ca. $10 \mathrm{~km}$ from the source. Before the discharge place the flow rate was on average 0.5 to $1.0 \mathrm{~m}^{3} / \mathrm{s}$, and the physicochemical and hydrobiological parameters qualified the water as III class of purity.

The basic product of the discussed plant was fibre-pulp, which was processed to other materials only to a small degree. The sulfite pulping method was used where cellulose fibres were separated with a $\mathrm{Ca}\left(\mathrm{HSO}_{3}\right)_{2}$ solution, containing 3 to $5 \%$ free $\mathrm{SO}_{2}$. The process of wood cuttings kiering took place at the increased temperature of 130 to $150^{\circ} \mathrm{C}$ and pressure 5 to $6 \mathrm{~atm}$. by 8 to 16 hours. In such conditions lignin were processed into soluble compounds, becoming the main contamination of fibred technological slurry. Slurry was discharged to the sedimentation tank, the initial efficiency of suspension removal was $90 \%$, but with time it deteriorated gradually, as the sedimentation tank was filled up. Owing to the considerable load of organic compounds, the slurry was used for the production of post-sulfite alcohol, animal food yeasts and liquor concentrate. The industrial utilization of the produced slurry resulted in the considerably lowered organic contamination charge.

The full production process, encompassing the unbleached and bleached pulp also involved other chemicals, e.g. $\mathrm{NaOH}$, $\mathrm{CaCO}_{3}, \mathrm{CaO}, \mathrm{Ca}(\mathrm{OCl})_{2}, \mathrm{Cl}_{2}, \mathrm{KCl}$, superphosphate, ammonia liquor and technological water. During the full activity of the plant produced ca. 31 to $24 \mathrm{Mt}$ cellulose per year, and the prevailing part (25 to $19 \mathrm{Mt}$ ) was sold.

\section{ENVIRONMENTAL INVESTIGATIONS - RESULTS AND EVALUATION}

The chemical production of fibre-pulp requires involving considerable amounts of production water, and consequently, waste slurry with organic compounds (ca. 50\% of dry wood mass) is produced, as well as part of liberated cellulose fibres. In the modern cellulose plants the post-production liquor concentrates are regenerated. Nonetheless, post-washing and post-dehydration waste is left over.

On the example of an old-type plant there was discussed a potential failure situation when the cleaning apparatuses break down, as well as the environmental consequences of discharging large quantities of organic matter and suspen- sions to superficial water. The basic mid-year data related with water-and-sewage management of the Plant, collected over a few years are presented in Table 3. All the enumerated data reveal that the production successively decreased, which was undoubtedly a consequence of introducing increasingly stricter environmental regulations.

The mid-year values of slurry discharged directly to the waste collector over the last five years of full productive activity were analyzed in detail. The results are listed in Table 4. For comparison's sake, in Table 5 there were presented the data characterizing the water of the $2 \mathrm{~km}$ length before the discharge point (in the analogous period).

Table 5. Superficial water state before the pulp-mill liquors affluent

\begin{tabular}{|c|c|c|c|}
\hline \multicolumn{4}{|c|}{ Primary parameters - average values per year } \\
\hline $\begin{array}{c}\mathrm{COD}-\mathrm{Mn} \\
{\left[\mathrm{mgO}_{2} / \mathrm{dm}^{3}\right]}\end{array}$ & $\begin{array}{c}\mathrm{BOD}_{5} \\
{\left[\mathrm{mgO}_{2} / \mathrm{dm}^{3}\right]}\end{array}$ & $\begin{array}{c}\text { Slurry } \\
{\left[\mathrm{mg} / \mathrm{dm}^{3}\right]}\end{array}$ & $\begin{array}{c}\text { Lignin } \\
{\left[\mathrm{mg} / \mathrm{dm}^{3}\right]}\end{array}$ \\
\hline $36.8-5.8$ & $33.7-1.8$ & $34.0-10.6$ & $10.9-1.4$ \\
\hline
\end{tabular}

Discharging chemical paper-pulp production slurry to clean superficial water must have negative environmental effect. The extreme contamination of water (even when the production has been considerably limited) was used for assessing the range of pollution and the course of self-cleaning processes. The results of annual river water measurements in four check points 1 to 4 localized at 4.6, 23.3, 24.2 and $31.5 \mathrm{~km}$ off the discharge outlet were analyzed. The mid-year results of 24 physicochemical parameters are presented in Table 6.

The behaviour of the main post production cellulose contaminants in the self-cleaning process: suspension and lignin and the related COD index are presented in Figures 1 and 2 , which is visually presented in lighter colour (Figure 3),



Figure 1. Advancement of the self-cleaning process in receiving the pulp-mill liquors

Table 3. Characteristics of the water-and-savage management - average values per year

\begin{tabular}{|c|c|c|c|c|c|}
\hline $\begin{array}{l}\text { Water } \\
\text { demand } \\
{\left[10^{6} \mathrm{~m}^{3}\right]}\end{array}$ & $\begin{array}{c}\text { Pulp-mill liquors } \\
\qquad Q\left[\mathrm{~m}^{3} / \mathrm{s}\right]\end{array}$ & \multicolumn{2}{|c|}{$\begin{array}{l}\text { Slurry: } \\
{\left[\mathrm{g} / \mathrm{dm}^{3}\right]}\end{array}$} & $\begin{array}{c}\text { Lignin sulfonates } \\
\text { acid } \\
{\left[\mathrm{mg} / \mathrm{dm}^{3}\right]}\end{array}$ & $\begin{array}{c}\mathrm{COD}-\mathrm{Cr} \\
{\left[\mathrm{gO}_{2} / \mathrm{dm}^{3}\right]}\end{array}$ \\
\hline $29.5-1.4$ & $1.07-0.27$ & $\begin{array}{l}\text { before decanter } \\
\text { after decanter } \\
\% \text { purification }\end{array}$ & $\begin{array}{l}0.29-0.08 \\
0.19-0.05 \\
79.6-19.2\end{array}$ & $1530-336$ & $3.7-0.8$ \\
\hline
\end{tabular}

Table 4. Characteristics of industrial pulp-mill liquors discharged directly to the watercourse

\begin{tabular}{|c|c|c|c|c|}
\hline \multirow[b]{2}{*}{ No. } & \multirow{2}{*}{$\begin{array}{l}\text { Pulp-mill liquors } \\
\qquad Q\left[\mathrm{~m}^{3} / \mathrm{s}\right]\end{array}$} & \multicolumn{3}{|c|}{ Principal impurities } \\
\hline & & $\begin{array}{c}\mathrm{COD}-\mathrm{Cr} \\
{\left[\mathrm{mgO}_{2} / \mathrm{dm}^{3}\right]}\end{array}$ & $\begin{array}{l}\text { Lignin sulfonates acid } \\
{\left[\begin{array}{l}{\left[\mathrm{mg} / \mathrm{dm}^{3}\right]} \\
\end{array}\right.}\end{array}$ & $\begin{array}{c}\text { Slurry } \\
{\left[\mathrm{mg} / \mathrm{dm}^{3}\right]}\end{array}$ \\
\hline 1 & 0.66 & 950.8 & 336.0 & 176.1 \\
\hline 2 & 0.64 & 874.2 & 354.6 & 183.9 \\
\hline 3 & 0.68 & 149.1 & 477.7 & 168.4 \\
\hline 4 & 0.53 & 1233.7 & 514.5 & 147.4 \\
\hline 5 & 0.27 & 776.1 & 449.0 & 73.3 \\
\hline \multicolumn{2}{|c|}{ Maximal value } & 3700.0 & 1529.6 & 192.5 \\
\hline
\end{tabular}


Table 6. The effectiveness of the self-purification process in the water-course polluted by pulp-mill liquors

\begin{tabular}{|c|c|c|c|c|c|c|}
\hline \multirow{2}{*}{ No. } & \multicolumn{6}{|c|}{ Characteristic of water-course } \\
\hline & Test points & Unit & 1 & 2 & 3 & 4 \\
\hline 1 & Distance & {$[\mathrm{km}]$} & 4.60 & 23.30 & 24.200 & 31.50 \\
\hline 2 & Continuous flow & {$\left[\mathrm{m}^{3} / \mathrm{s}\right]$} & 0.12 & 0.31 & 0.025 & 0.11 \\
\hline \multicolumn{7}{|c|}{$\begin{array}{l}\text { The water-course: the receiver of pulp-mill liquors } \\
\text { physicochemical parameters - average values per year }\end{array}$} \\
\hline 1 & Temperature & ${ }^{0} \mathrm{C}$ & 14.8 & 14.0 & 10.3 & 11.2 \\
\hline 2 & Colour & $\mathrm{mg} \mathrm{Pt} / \mathrm{dm}^{3}$ & 170.0 & 152.5 & 12.5 & 10.0 \\
\hline 3 & Reaction & $\mathrm{pH}$ & $7.1-7.7$ & $7.1-7.5$ & $7.9-8.1$ & $7.8-8.1$ \\
\hline 4 & Conductivity & $\mu \mathrm{S} / \mathrm{cm}$ & 935.0 & 920.0 & 905.0 & 650.0 \\
\hline 5 & Oxygen (free) & $\mathrm{mg} \mathrm{O}_{2} / \mathrm{dm}^{3}$ & 0.1 & 0.1 & 7.0 & 7.8 \\
\hline 6 & $\mathrm{BOD}_{5}$ & $\mathrm{mg} \mathrm{O}_{2} / \mathrm{dm}^{3}$ & 154.5 & 125.4 & 3.2 & 4.9 \\
\hline 7 & COD-Mn & $\mathrm{mg} \mathrm{O}_{2} / \mathrm{dm}^{3}$ & 527.5 & 249.5 & 6.6 & 8.0 \\
\hline 8 & COD-Cr & $\mathrm{mg} \mathrm{O}_{2} / \mathrm{dm}^{3}$ & 567.0 & 469.0 & 22.4 & 25.7 \\
\hline 9 & Chlorine(I) & $\mathrm{mg} \mathrm{Cl} / \mathrm{dm}^{3}$ & 72.1 & 85.8 & 38.4 & 53.5 \\
\hline 10 & Sulfate(VI) & $\mathrm{mg} \mathrm{SO}_{4} / \mathrm{dm}^{3}$ & 245.5 & 219.0 & 144.0 & 132.0 \\
\hline 11 & Dissolved solids & $\mathrm{mg} / \mathrm{dm}^{3}$ & 1138.0 & 1133.0 & 543.5 & 474.0 \\
\hline 12 & Suspended solids & $\mathrm{mg} / \mathrm{dm}^{3}$ & 158.5 & 132.2 & 17.3 & 18.9 \\
\hline 13 & Total hardness & $\mathrm{mval} / \mathrm{dm}^{3}$ & - & - & 11.7 & 10.0 \\
\hline 14 & Ammonia nitrogen & $\mathrm{mg} \mathrm{N} / \mathrm{dm}^{3}$ & 1.1 & 1.5 & 0.4 & 3.8 \\
\hline 15 & Nitrate nitrogen & $\mathrm{mg} \mathrm{N} / \mathrm{dm}^{3}$ & - & - & 6.4 & 4.9 \\
\hline 16 & Total nitrogen & $\mathrm{mg} \mathrm{N} / \mathrm{dm}^{3}$ & 2.2 & 4.3 & 1.0 & 7.8 \\
\hline 17 & Phosphate & $\mathrm{mg} \mathrm{PO}_{4} / \mathrm{dm}^{3}$ & - & - & 0.7 & 2.3 \\
\hline 18 & Total phosphor & $\mathrm{mg} \mathrm{PO}_{4} / \mathrm{dm}^{3}$ & - & - & 1.6 & 6.4 \\
\hline 19 & Phenol & $\mathrm{mg} / \mathrm{dm}^{3}$ & $1.5 \cdot 10^{-2}$ & $1.5 \cdot 10^{-2}$ & $2 \cdot 10^{-3}$ & $1 \cdot 10^{-3}$ \\
\hline 20 & Detergents (anionic) & $\mathrm{mg} / \mathrm{dm}^{3}$ & - & - & 0.8 & 0.8 \\
\hline 21 & Etheric exstract & $\mathrm{mg} / \mathrm{dm}^{3}$ & 2.7 & 2.2 & 1.2 & 1.2 \\
\hline 22 & Manganese(II) & $\mathrm{mg} \mathrm{Mn} / \mathrm{dm}^{3}$ & 0.4 & 0.7 & 0.3 & 0.5 \\
\hline 23 & Iron (total) & $\mathrm{mg} \mathrm{Fe} / \mathrm{dm}^{3}$ & 1.8 & 2.5 & 0.3 & 0.7 \\
\hline 24 & Lignin & $\mathrm{mg} / \mathrm{dm}^{3}$ & 414.5 & 310.0 & 2.0 & 3.2 \\
\hline
\end{tabular}

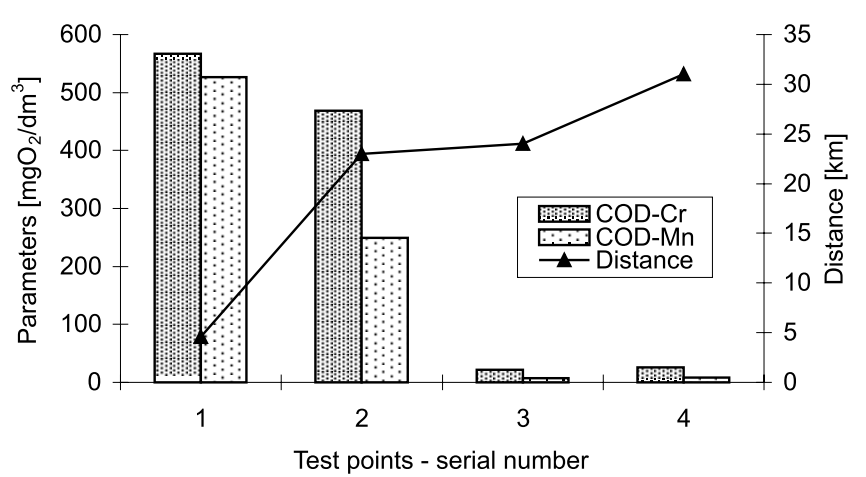

Figure 2. Advancement of the self-cleaning process in receiving the pulp-mill liquors
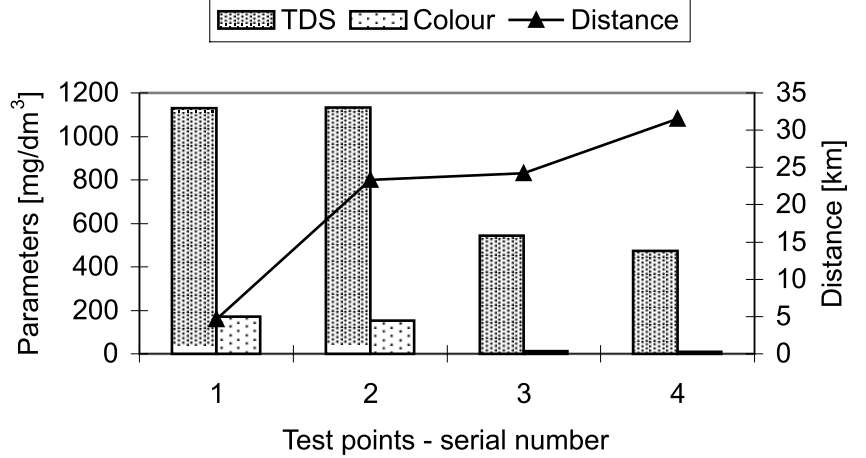

Figure 3. Change of the water-course environment by the self-purification process

together with the total dissolved solids (TDS). The presented results reveal that the self-cleaning effect became fully visible at the 25 to $30 \mathrm{~km}$ of the watercourse, where the slower river current turned out to be an advantageous factor. Superficial water regained its prior state. The ultimate proof of the completed process of contamination degradation was a definite improvement of oxygen conditions (item 5 in Table 6).

\section{CONCLUDING REMARKS}

World's paper and cardboad consumption is constantly increasing. In 2005 the demand for paper and cardboard as well as for primary pulp was $366 \mathrm{mln}$ ton and $88.5 \mathrm{mln}$ ton, respectively. A similar trend can be observed in 17 Europe's countries belonging to The Confederation of European Paper Industries (CEPI): the production in 2006 increased by ca. $7.5 \%$ as compared to the year 2003, and ca. $102 \mathrm{mln}$ ton of paper and cardboard were produced. Poland, with its global production of ca. $2.9 \mathrm{mln}$ ton occupies a 10th position. Satisfying the market needs, CEPI countries produced on the whole about $43.5 \mathrm{mln}$ ton of cellulose-pulp (in integrated and market system), in that $1.1 \mathrm{mln}$ ton were produced in Polish cellulose plants ${ }^{8}$. Following the World's trends, about $80 \%$ of cellulose pulp needed for the paper and cardboard production were sulfate paper-pulp.

Various kinds of wood are used as the basic material, and the process itself involves considerable quantities of technological water, where the organic compounds from the cellulose, lignin in particular, get in. Depending on the stage of processing, the post-production slurry varies in the contamination content (can be very high). The averaging operation (dissolution at the Plant) lowers the value to 0.5 to $1.0 \mathrm{~g}$ $\mathrm{O}_{2} / \mathrm{dm}^{3}$. This type of water requires cleaning in a biologic slurry treatment pit, which is considered to be BAT, protecting the collector against excessive discharges.

The analysis of the data characterizing Poland's paper plants reveals ${ }^{9}$ that the fresh water consumption and the quantity of discharged water vary, depending on the type of produced paper, e.g. $23 \mathrm{~m}^{3}$ slurry per ton of newspaper-pulp, and the BAT value $\left(15 \mathrm{~m}^{3}\right)$ may be exceeded. After cleaning, the newspaper-pulp post-production slurry still may contain a charge of contaminations (per ton of product): to $1.8 \mathrm{~kg}$ 
of suspension (BAT $=0.2$ to $0.4 \mathrm{~kg}$ ) and $\mathrm{COD}-\mathrm{Cr}=5.2$ to $12.5 \mathrm{O}_{2}$ (BAT $=0.5$ to 2.0 ). Presently, the optimized waterand-slurry management in the cellulose-and-paper sector is a peer production component. Monitoring of technological waters in the plant creates chances for minimizing the charge of specific contaminations discharged to the water environment, which could be degradable to a varying degree.

Realized within own research program no. 10.10.190.343 and statute research program no. 11.11.100.196

\section{LITERATURE CITED}

1. European Commission, Sewilla (2001): Reference Dokument on Best Available Techniques (BAT) in the Pulp and Paper Industry - Integrated Pollution Prevention and Control (IPPC) (http://eippcb.irc.es); Ministerstwo Środowiska, Warszawa (2004) (www.mos.gov.pl: 1092).

2. Michniewicz, M. (Ed.) (2005): Best Available Techniques (BAT. Guidelines for the Pulp and Paper Branch, Ministerstwo Środowiska, Warszawa (http://ippc.mos.gov.pl/BAT).

3. Michniewicz, M., Malinowski, E. (2006). Determinants and limitations of industry growth connected with environmental protection requirement (in Polish). Przegl. Papiern. $6,322-324$.

4. Jagiełła, A., Michniewicz M. \& Ledakowicz, S. (2005). Influence of ozonation on lignin compounds degradation in pulp and paper effluents (in Polish). Przegl. Papiern. 3, 166 -170 .

5. Kopania, E. \& Wandelt, P. (2006). Selective delignification and TCF bleaching of high-yield kraft pine pulp with use of activated hydrogen peroxid (in Polish). Przegl. Papiern. 12, 717 - 721.

6. Michniewicz, M., Jagiełła, A. \& Ledakowicz, S. (2005). Resin acids degradation by ozon and other oxidizing agents (in Polish). Przegl. Papiern. 10, $620-623$.

7. Rulewska, M. (2006). Puriffication and in-house monitoring of pulp-mill liquors in Mondi Packing Paper Świecie S.A. (in Polish). Przegl. Papiern. 11, 639 - 640.

8. Fornalski, Z. (2007). Production and consumption of paper and cardboard in Poland 2006 on background of European countries (in Polish). Przegl. Papiern. 9, 509 - 513.

9. Janiga, M., Michniewicz, M., Sokół, A. \& Żubrzak, M. (2006) Situation of polish paper industry in view of BAT (in Polish). Przegl. Papiern. 2, 95 - 103. 